\title{
Particle Image Velocimetry Measurements of Flow Over an Ogee-Type Weir in a Hydraulic Flume
}

\author{
Jarosław Biegowski ${ }^{1}$ Maciej Paprota ${ }^{2}$ (D) $\cdot$ Wojciech Sulisz ${ }^{2}$
}

Received: 29 January 2020 / Revised: 8 June 2020 / Accepted: 10 June 2020/Published online: 10 July 2020

(C) The Author(s) 2020

\begin{abstract}
Laboratory tests of water flowing over a modified ogee weir are carried out in a wave-current flume for two different scales. A model of a weir representing a part of a spillway section of the existing Włocławek dam (Vistula River, Poland) is mounted in a wave-current flume. The Froude similarity law is used to simulate the flow over a real damming structure at 1:25 and 1:50 scales. Particle image velocimetry methods are employed to measure a flow velocity field over the crest of the weir model. The system is capable of providing high fidelity velocity fields at sampling rates of $10 \mathrm{~Hz}$ and $50 \mathrm{~Hz}$. Detailed information on flow characteristics is extracted from the instantaneous velocity field measurements to provide a comprehensive description of the kinematics of a weir flow at discharges corresponding to hydrological events with return periods of 100 and 1000 years, revealing some interesting spatial features. The geometry of the weir results in the development of a characteristic circulation cell, which is relatively wide for the lower discharge. When the flow intensity increases, a triangular circulation develops behind the weir crest instead. Moreover, sudden changes in the flow regime lead to the rapid formation of vortex structures, which propagate downstream at speeds ranging from 0.3 to $1 \mathrm{~m} \mathrm{~s}^{-1}$. The origin of eddy formation is identified at the upstream and downstream ends of the weir crest for respective average velocities at the crest of approx. $0.6 \mathrm{~m} \mathrm{~s}^{-1}$ and $1.2 \mathrm{~m} \mathrm{~s}^{-1}$.
\end{abstract}

Keywords Weir flow · Particle image velocimetry (PIV) - Wave-current flume · Vortex structure

\section{Introduction}

Dam engineering structures are widely used to raise the water level and thus secure safe retention and storage of water for a number of fundamental purposes, such as navigation, irrigation, water supply, hydroelectricity, regulation of rivers, flood control, etc.[1]. Weirs constitute a

Maciej Paprota

mapap@ibwpan.gda.pl

Jarosław Biegowski

jarbieg@ibwpan.gda.pl

Wojciech Sulisz

sulisz@ibwpan.gda.pl

1 Department of Coastal Engineering and Dynamics, Institute of Hydro-Engineering, Polish Academy of Sciences, Gdańsk, Poland

2 Department of Wave Mechanics and Structural Dynamics, Institute of Hydro-Engineering, Polish Academy of Sciences, Gdańsk, Poland common type of hydraulic damming solutions that either form part of an embankment or a concrete dam, or are built as standalone structures. There is no universal type of a weir, as its configuration differs depending on the local requirements and technical capabilities. Weirs are constructed as sharp-crested and broad-crested structures. Sharp-crested weirs include rectangular, triangular, and trapezoidal notches. Broad-crested weirs are generally constructed as concrete blocks with a very broad sill. The weir section of a barrage may include weirs of different forms, such as a sloping weir, a vertical drop weir, an ogee weir, and a labyrinth weir with a zig-zag crest [1]. A fundamental function of a weir is to block a flowing stream of water and eventually force a hydraulic overflow over the weir crest. Safe and economic design of a weir requires determining the hydrodynamic loads acting on the structure to properly satisfy conditions of stability as well as recognising flow kinematics to ensure a necessary amount of water being discharged over the crest. Most of design works uses generally accepted standards and guidelines 
based on empirical formulas derived for typical geometries and types of weirs. However, the final engineering project is usually preceded by experimental modelling of admitted hydraulic solutions at a model scale in a hydraulic flume.

In Poland, a good example of a dam design process supported by laboratory experiments is the construction of the Włocławek barrage, which was built in 1962-1970 as the first element of a lower Vistula cascade originally planned as a set of eight low-head barrages [2,3]. The total length of a 10-span concrete spillway section of the Włocławek dam is $200 \mathrm{~m}$ [4]. The weir crest elevation is $50.5 \mathrm{~m}$ a.s.l. The upstream and downstream beds are located at 42 and $41 \mathrm{~m}$ a.s.l., respectively. The normal damming level is $57.3 \mathrm{~m}$ a.s.l. The design values of maximum discharge rates $Q_{1 \%}$ and $Q_{0.1 \%}$, corresponding to extreme hydrological events with return periods of 100 and 1000 years, are estimated as high as $9745 \mathrm{~m}^{3} \mathrm{~s}^{-1}$ and $12,514 \mathrm{~m}^{3} \mathrm{~s}^{-1}$. The design of the spillway section of the Włocławek barrage allowed for an important meteorological factor, which is the risk of ice formation upstream of the dam. Hence, the spillway section was designed to allow ice sheets to pass downstream over the head regulator gates of a plain vertical lift type. This involved a modification to the original ogee weir profile, resulting in the construction of an indentation behind the crest to hide the gates.

The construction of the Włocławek dam was preceded by an experimental model study of the hydraulic properties of the spillway section and water flow characteristics in the hydraulic laboratory of the Institute of Hydro-Engineering, Polish Academy of Sciences, Gdańsk in 1959. The investigations included testing of the original design of the weir using the 1:50 model scale, selected according to the Froude similarity law, and measurements of hydrodynamic loads at the 1:25 model scale. In the course of experiments, water flow velocities were measured using state-of-the-art Pitot tubes and surface markers (floaters). A number of velocity profiles were obtained along the streamwise direction of the downstream side of the weir. However, velocities in a direct vicinity of the weir model were not measured. Velocity data acquisition around the weir model would have been extremely long and laborious due to the limited number of Pitot tubes and a relatively large number of acquisition points necessary for a reasonable spatial resolution of a velocity vector field for engineering purposes.

Since the development of the PIV technique and its adaptation to fluid flows, effective measurements of the evolution of instantaneous velocity fields have become feasible [5]. Common problems of a coarse resolution and an intrusive character of single-point sensors (such as a Pitot tube) have been finally resolved. With respect to river flows, PIV techniques were widely applied to estimate water surface velocities using naturally occurring foam as a tracer [6]. This method, known as Large Scale Particle Image Velocimetry (LS-PIV), has become a popular field measuring technique for evaluating kinematics of surface river flows [7-9]. Successful implementation of PIV in river flow measurements encouraged researchers to derive a methodology based on PIV and Particle Tracking Velocimetry (PTV), which resulted in the first operational version of the RIVeR package (Rectification of Image Velocity Results) for large scale velocimetry [10].

It is thus surprising that the new capabilities of the PIV method are only seldom applied to the classical scientific problem of flow over a weir. Most of research still relies on Acoustic Doppler Velocimetry (ADV) point measurements. For instance, ADV was used to measure flow velocities for streamlined weirs [11] and labyrinth weirs [12]. Moreover, numerical techniques were also used because of the modest availability of measuring equipment to investigate weir flows [13] and other important problems of river hydraulics (see e.g. [14].). Application of PIV to specific problems of weir hydraulics is relatively scarce. A few examples are studies of flow over a stepped spillway $[15,16]$ or the oscillating behaviour of a liquid nappe [17]. Recently, an interesting problem of flow over an ogee spillway crest was investigated by laboratory techniques based on Bubble Image Velocimetry (BIV) [18], where bubbles were used as tracers for the PIV analysis. Another recent example of application of imaging techniques used to investigate flow characteristics is the study on horizontal dense flow spreading in ambient water driven by inclined and convergent surface jets [19]. In this study, a system of two cameras captured spreading patterns of horizontal dense flow of the coloured jet fluid in an experimental flume with Plexiglas walls.

In view of the above, the present study deals with physical tests of water flowing over a submerged damming structure and PIV measurements in a wave-current flume for two weir models corresponding to model scales of 1:25 and 1:50. The weir model under investigation is based on a real engineering solution, which is a part of the spillway section of the Włocławek dam. Weir flow kinematics are determined by a PIV system comprising a high-speed camera and a laser. The information on the spatial characteristics of velocity vector fields under various parameters of flow is used to study the intrinsic features of water flowing in the vicinity of the damming structure. Previous laboratory investigations of flow characteristics covered only time-averaged velocity profiles at some distance from the weir model. The present experimental study provides a comprehensive description of the kinematics of flow directly over the weir model of the Włocławek dam at discharges corresponding to hydrological events with return periods of 100 and 1000 years. The resulting comprehensive database of experimental velocity 
measurements may serve as a basis for validation of the available numerical models of computational fluid dynamics used for simulations and predictions of a flow field in flow-structure interaction problems.

\section{Materials and Methods}

\subsection{Experimental Setup}

Experimental tests are carried out in the hydraulic laboratory of the Institute of Hydro-Engineering, Polish Academy of Sciences (IHE PAS). A major part of the laboratory consists of a wave-current flume, which is a glass-sided basin filled with water of length $l=64 \mathrm{~m}$ and width $b=0.6 \mathrm{~m}$. The height of the flume walls is $1.4 \mathrm{~m}$. The operational water depth $(h)$ varies between $0.2 \mathrm{~m}$ and $0.8 \mathrm{~m}$. The flume is equipped with a piston-type wavemaker driven by an electric motor and a set of two $50 \mathrm{~Hz}$ FLYGT PP 4640 hydraulic pumps installed independently inside two tanks at both ends of the flume. Under the flume bottom, a $0.5 \mathrm{~m}$ diameter steel pipe is installed for recirculation of water, together with a Techmag FM 300 electro-magnetic flowmeter, which allows the net discharge $Q$ to be monitored during laboratory tests with $0.5 \%$ accuracy. The laboratory flume environment makes it possible to test physical models by standard measuring procedures as well as by measuring methods based on imaging techniques, such as PIV (see e.g. [20-22].). A general scheme of a wave-current flume with a wavecurrent generating system is presented as a side view in Fig. 1.

In the present study, only the flow-generating function of the wave-current generating system is used. The wavemaker plate is removed from the flume to ensure free flow of water (Fig. 1). Only the system of pumps is used to generate a steady current in the flume. Hence, the most important factors determining the capabilities of the flowgenerating system are the minimum and maximum discharges of the pumps, which are $0.03 \mathrm{~m}^{3} \mathrm{~s}^{-1}$ and $0.33 \mathrm{~m}^{3} \mathrm{~s}^{-1}$, respectively, for working pump frequencies $f_{\text {pump }}$ of $20 \mathrm{~Hz}$ and $50 \mathrm{~Hz}$. However, due to energy losses along the flume and the pipe, the maximum net discharge is lower. Depending on the operational water depth, the pumps are capable of producing net discharges ranging from $0.08 \mathrm{~m}^{3} \mathrm{~s}^{-1}$ to $0.19 \mathrm{~m}^{3} \mathrm{~s}^{-1}$ for $h=0.3 \mathrm{~m}$ and from $0.09 \mathrm{~m}^{3} \mathrm{~s}^{-1}$ to $0.24 \mathrm{~m}^{3} \mathrm{~s}^{-1}$ for $h=0.6 \mathrm{~m}$, corresponding to average flow velocities ranging from $0.44 \mathrm{~m} \mathrm{~s}^{-1}$ to $1.05 \mathrm{~m} \mathrm{~s}^{-1}$ for $h=0.3 \mathrm{~m} \mathrm{and} \mathrm{from} 0.25 \mathrm{~m} \mathrm{~s}^{-1}$ to $0.67 \mathrm{~m} \mathrm{~s}^{-1}$ for $h=0.6 \mathrm{~m}$. In Fig. 2, the net discharge generated by pump 2 is presented as a function of the pump working frequency. It may be seen from the graph that increasing the working frequency of pump 2 results in a nearly linear increase in discharge. However, some small deviations from the linear $Q-f_{\text {pump }}$ dependency are apparent for the highest working frequencies of the pump and for the lower water depth $h=0.3 \mathrm{~m}$ because of the incomplete submergence of the pump in the flume tank.

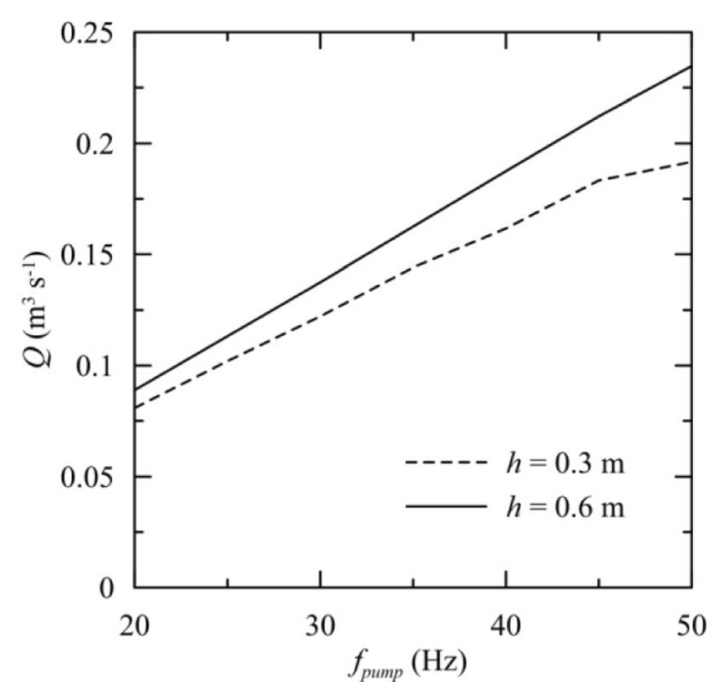

Fig. 2 Net discharge characteristics of pump 2

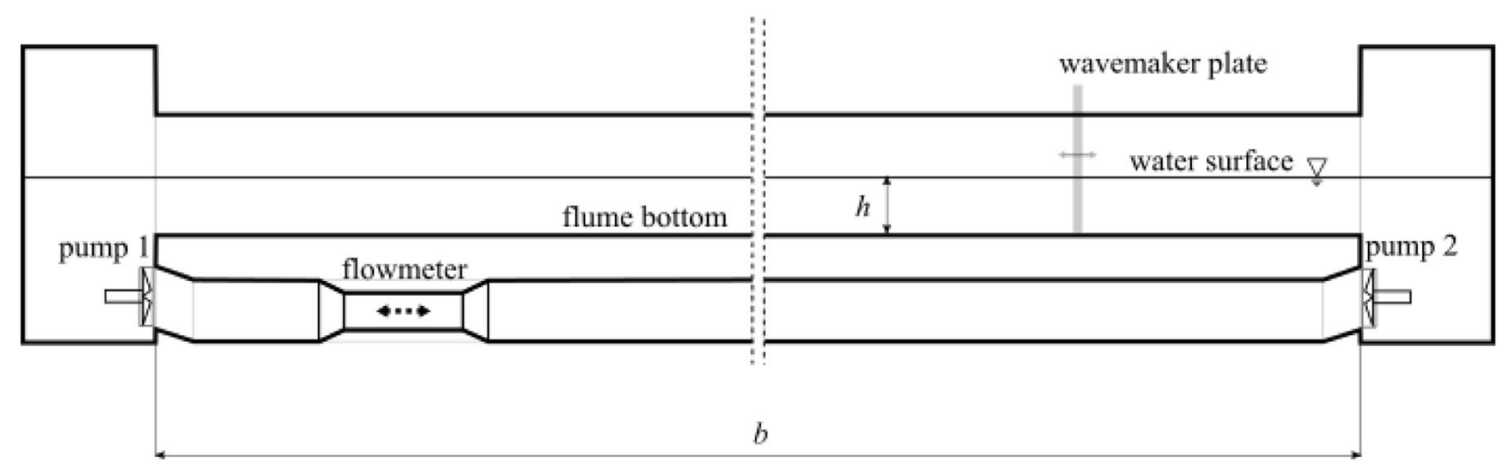

Fig. 1 A schematic side view of the IHE PAS wave-current flume 


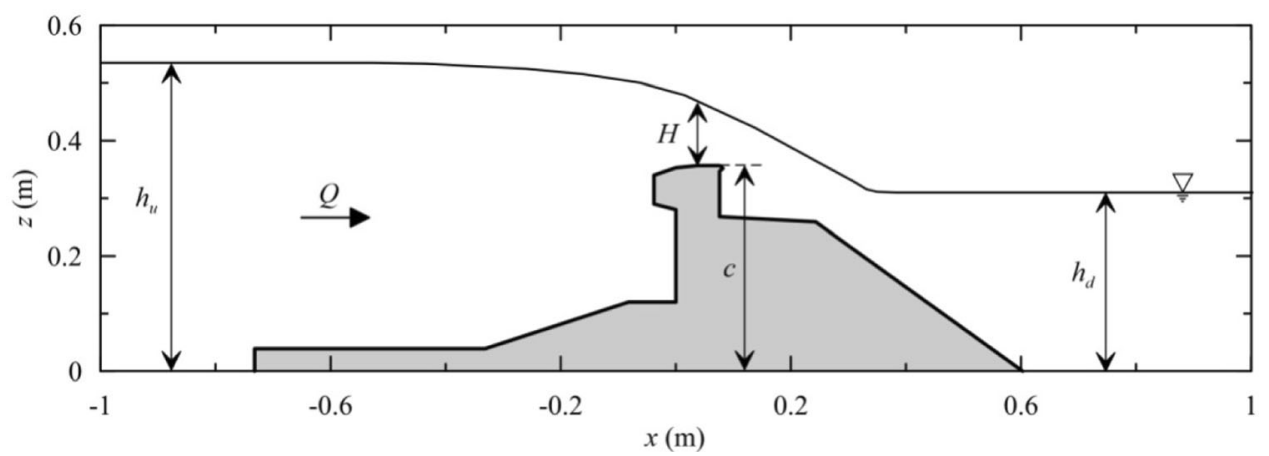

Fig. 3 A schematic cross section of a weir corresponding to the 1:25 model scale
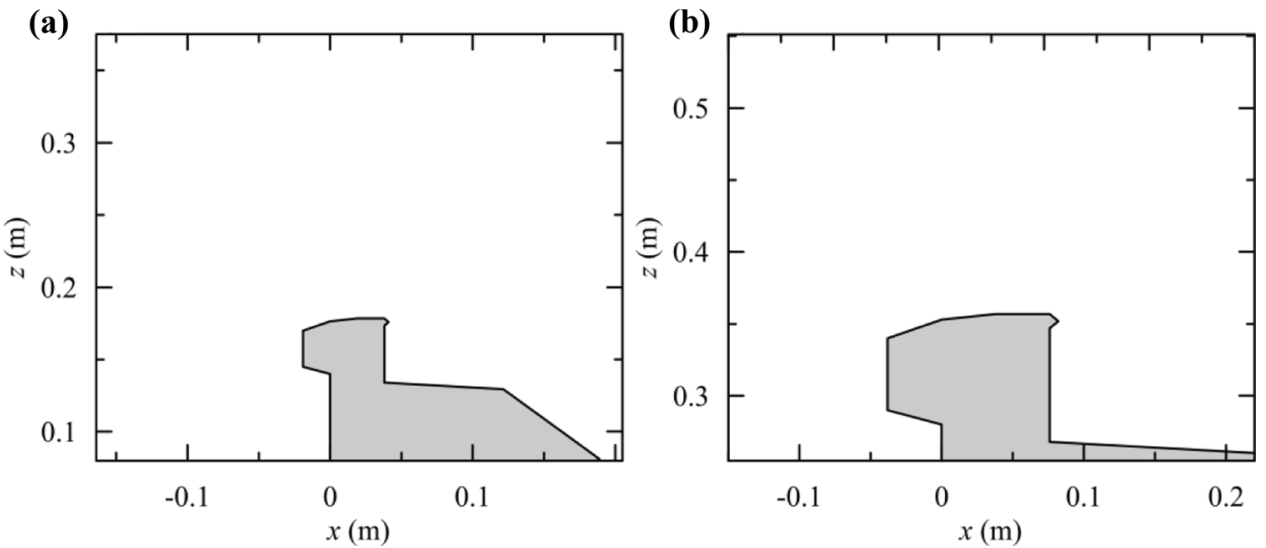

Fig. 4 PIV coverage area of flow over the weir: a scale factor 1:50, b scale factor 1:25

Table 1 Basic hydraulic parameters of laboratory PIV measurements of flow over a weir

\begin{tabular}{llllllllll}
\hline $\begin{array}{l}\text { Test } \\
\text { no. }\end{array}$ & Scale & $\begin{array}{l}\text { Hydrostatic } \\
\text { water depth } \\
h(\mathrm{~m})\end{array}$ & $\begin{array}{l}\text { Pump working } \\
\text { frequency } f_{\text {pump }} \\
(\mathrm{Hz})\end{array}$ & $\begin{array}{l}\text { Net } \\
\text { discharge } \\
Q\left(\mathrm{~m}^{3} \mathrm{~s}^{-1}\right)\end{array}$ & $\begin{array}{l}\text { Upstream } \\
\text { water } \\
\text { depth } h_{\mathrm{u}}\end{array}$ & $\begin{array}{l}\text { Crest } \\
\text { height } \\
C(\mathrm{~m})\end{array}$ & $\begin{array}{l}\text { Crest head } \\
\text { of water } \\
H(\mathrm{~m})\end{array}$ & $\begin{array}{l}\text { Downstream } \\
\text { water depth } h_{\mathrm{d}} \\
(\mathrm{m})\end{array}$ & $\begin{array}{l}\text { Average velocity at } \\
\text { crest head } v_{\mathrm{H}} \\
\left(\mathrm{m} \mathrm{s} \mathrm{s}^{-1}\right)\end{array}$ \\
\hline WF01 & $1: 50$ & 0.3 & 20 & 0.061 & 0.32 & 0.18 & 0.13 & 0.28 & 0.78 \\
WF02 & $1: 50$ & 0.3 & 24 & 0.078 & 0.33 & 0.18 & 0.13 & 0.26 & 1.00 \\
WF03 & $1: 50$ & 0.3 & 40 & 0.130 & 0.36 & 0.18 & 0.12 & 0.26 & 1.80 \\
WF04 & $1: 25$ & 0.4 & 20 & 0.034 & 0.47 & 0.36 & 0.08 & 0.29 & 0.70 \\
WF05 & $1: 25$ & 0.4 & 30 & 0.072 & 0.52 & 0.36 & 0.11 & $0.09^{*}$ & 1.09 \\
WF06 & $1: 25$ & 0.4 & 42 & 0.122 & 0.57 & 0.36 & 0.15 & $0.10^{*}$ & 1.36 \\
WF07 & $1: 25$ & 0.5 & 20 & 0.070 & 0.53 & 0.36 & 0.13 & 0.46 & 0.90 \\
WF08 & $1: 25$ & 0.5 & 42 & 0.152 & 0.60 & 0.36 & 0.19 & $0.14^{*}$ & 1.33 \\
WF09 & $1: 25$ & 0.5 & 50 & 0.188 & 0.63 & 0.36 & 0.21 & $0.15^{*}$ & 1.49 \\
WF10 & $1: 25$ & 0.6 & 20 & 0.083 & 0.61 & 0.36 & 0.25 & 0.60 & 0.55 \\
WF11 & $1: 25$ & 0.6 & 42 & 0.175 & 0.64 & 0.36 & 0.23 & 0.51 & 1.27 \\
WF12 & $1: 25$ & 0.6 & 50 & 0.215 & 0.65 & 0.36 & 0.23 & 0.43 & 1.56 \\
\hline
\end{tabular}

*Downstream water depth at supercritical flow (the upstream side of a hydraulic jump)

Weir models of two different physical scales, 1:50 and $1: 25$, are installed in the flume. The models are made of waterproof plywood painted with matte black paint. The shape and physical dimensions of the models correspond to the geometry of a segment of a narrow-crested spillway section of the existing Włocławek dam. In Fig. 3, a 

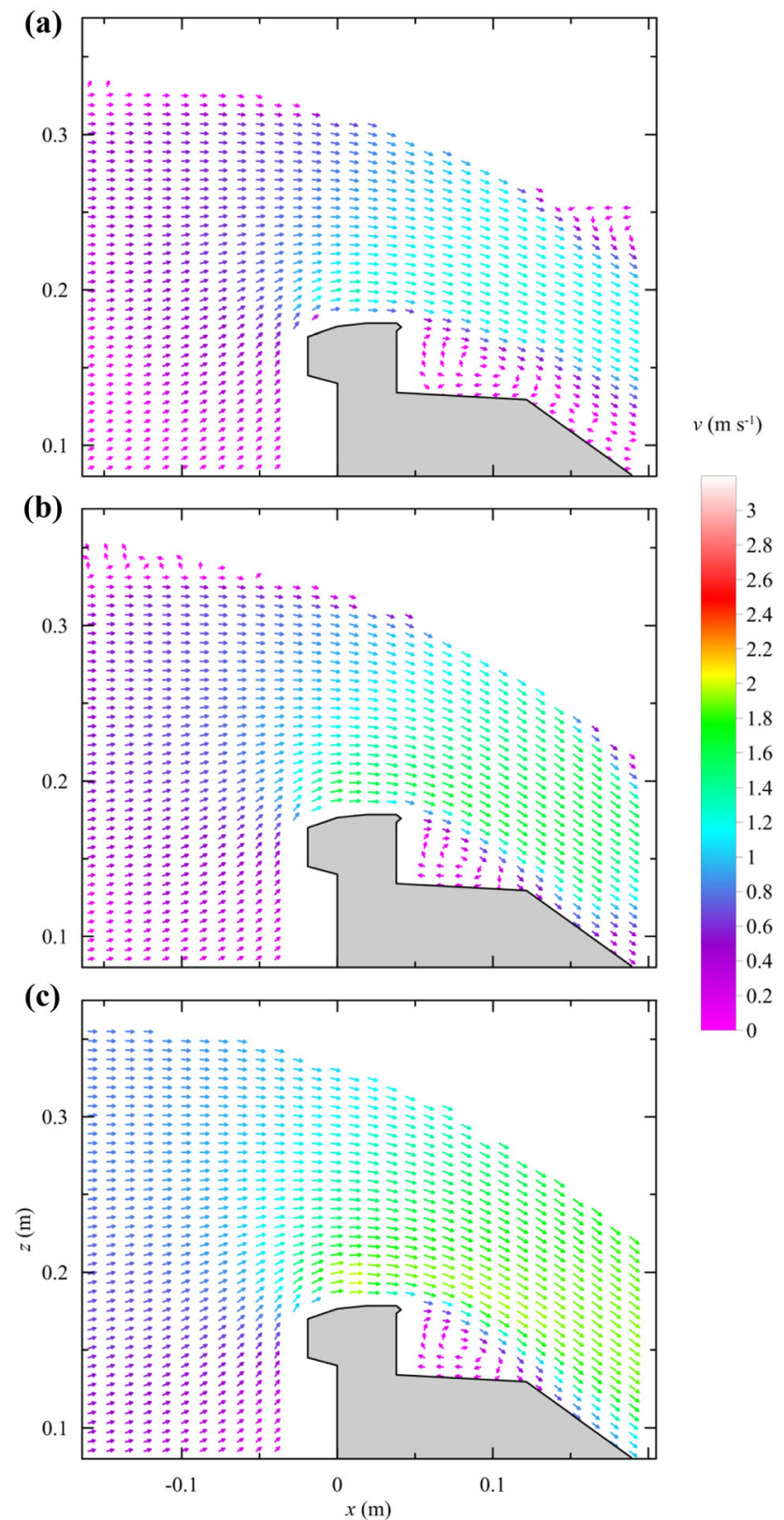

Fig. 5 Average velocity fields of flow over the 1:50 weir model; ac tests WF01-WF03

schematic cross section of the model is presented with dimensions corresponding to the 1:25 scale. The upstream vertical wall of the two scale models coincides with the $z$ axis $(x=0 \mathrm{~m})$ and is located $39 \mathrm{~m}$ away from the inflow boundary of pump 1 (Fig. 3).

The spillway wall faces are vertical with an offset upstream and a small rounded edging at the top of the crest downstream. The crest is relatively narrow. The weir and the associated water flow are characterised by the following parameters: the upstream water depth $h_{\mathrm{u}}$, the downstream water depth $h_{\mathrm{d}}$, the crest height $C$, and the head of water above the crest $H$. The head height and
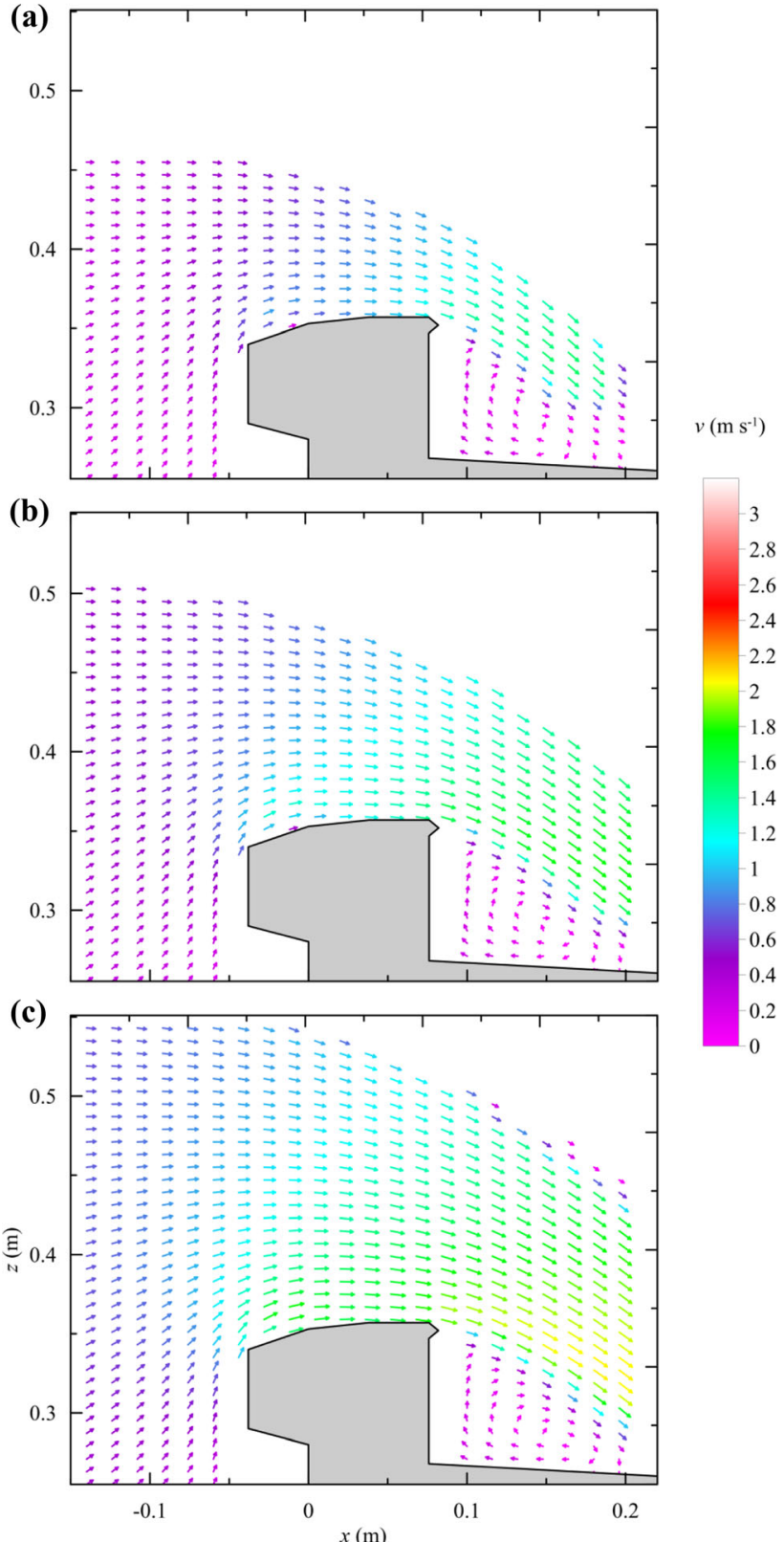

Fig. 6 Average velocity fields of flow over the 1:25 weir model; ac tests WF04-WF06

upstream/downstream water depths depend on the initial water depth in the flume (at the hydrostatic state) and the net discharge produced by the pumping system.

\subsection{PIV Measurements}

The instantaneous velocity fields of flow over the weir are recorded by a state-of-the-art 2D Flowmaster PIV system comprising a high-speed camera with a charge-coupled device $(C C D)$ having a resolution of $1280 \times 1024$ pixels and a neodymium-doped yttrium-aluminium-garnet 

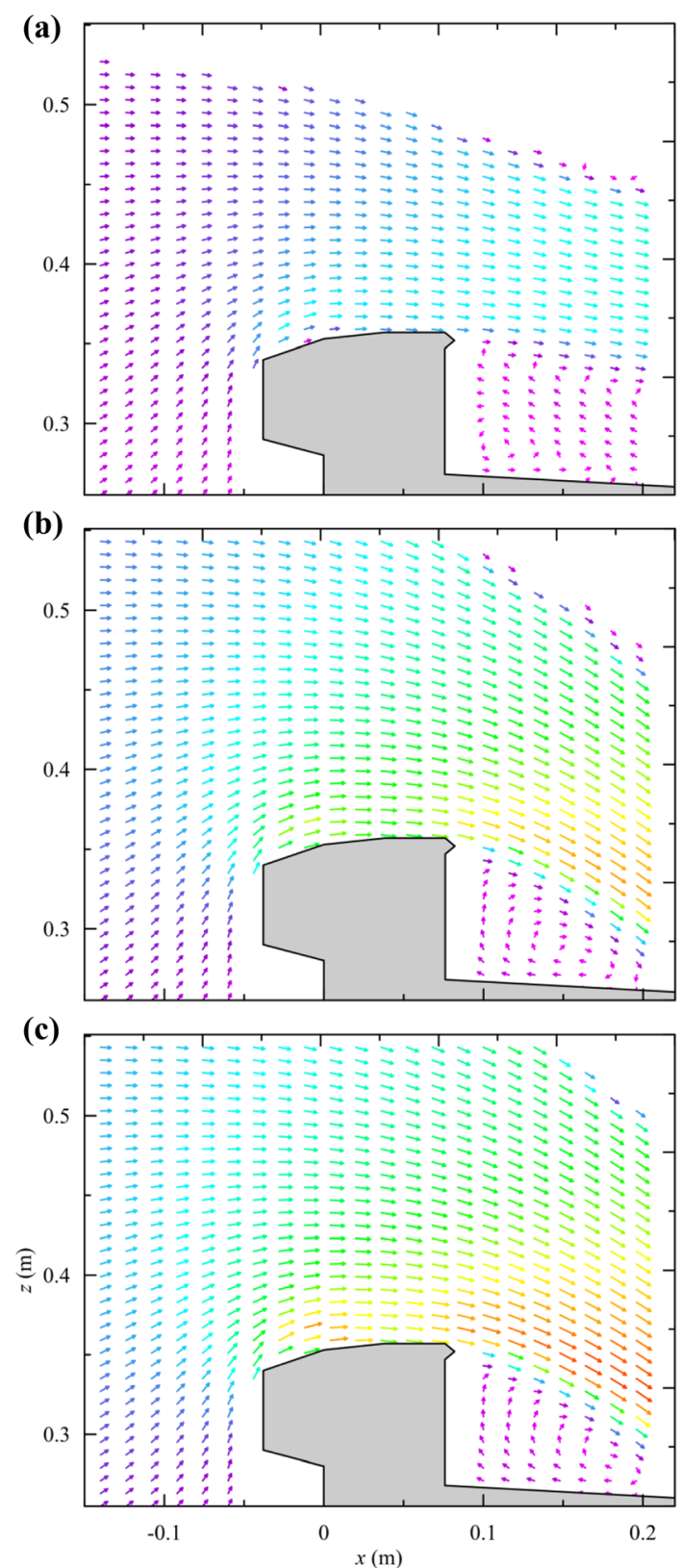

Fig. 7 Average velocity fields of flow over the 1:25 weir model; ac tests WF07-WF09

(Nd:YAG) $50 \mathrm{~mJ}$ dual laser-head system operating at a maximum repetition rate of $50 \mathrm{~Hz}$. Hollow glass spheres are suspended in water and used as seeding tracer particles. They are illuminated by a pulsed sheet of laser light and recorded as a pair of two single-exposure images by a camera. The two camera exposures are separated by an interval of $1.8 \mathrm{~ms}$. Based on the time interval between images and the average displacement of the seeding material, the velocity vector is determined in selected subareas called interrogation windows. More information on the principle of PIV measurements and analysis of
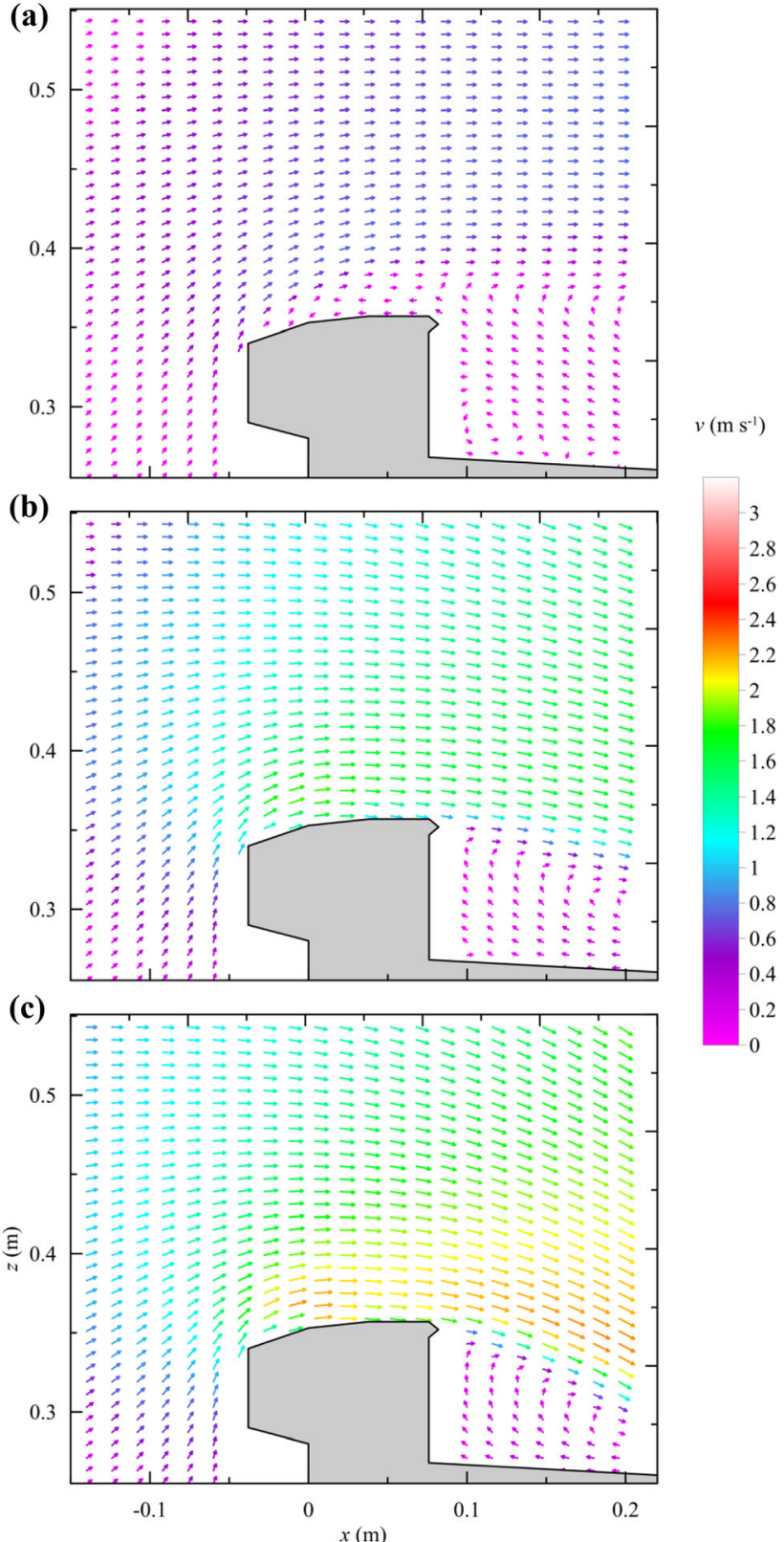

Fig. 8 Average velocity fields of flow over the 1:25 weir model; ac tests WF10-WF12

results may be found in papers on the use of PIV techniques in experimental fluid mechanics (see e.g. [5, 23].). Velocity measurements are performed in a plane parallel to the direction of flow and the glass walls of the flume. The PIV camera traces particle displacements by recording pairs of images in a $0.369 \mathrm{~m} \times 0.295 \mathrm{~m}$ field of view with a fixed sampling frequency $f_{\text {PIV }}$. The PIV coverage for the two model scales is depicted in Fig. 4

A double frame/double exposure method, based on the cross correlation of two images, is used to calculate the spatial distribution of velocity vectors at consecutive time 


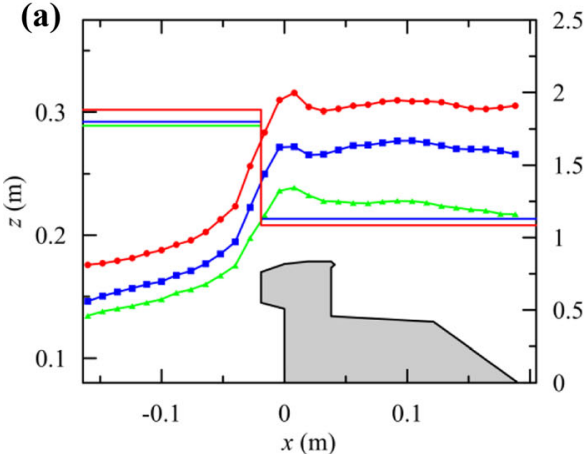

(c)

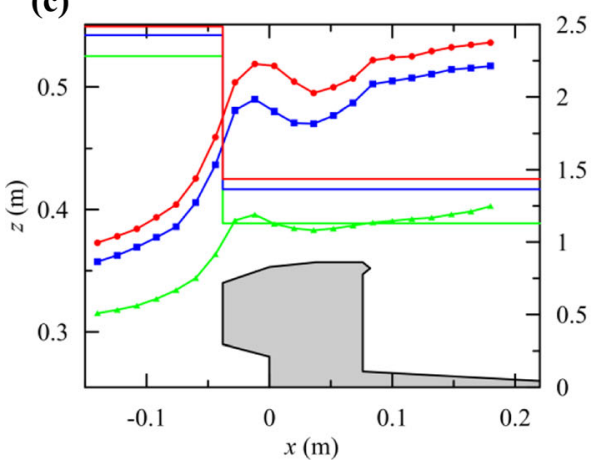

(b)

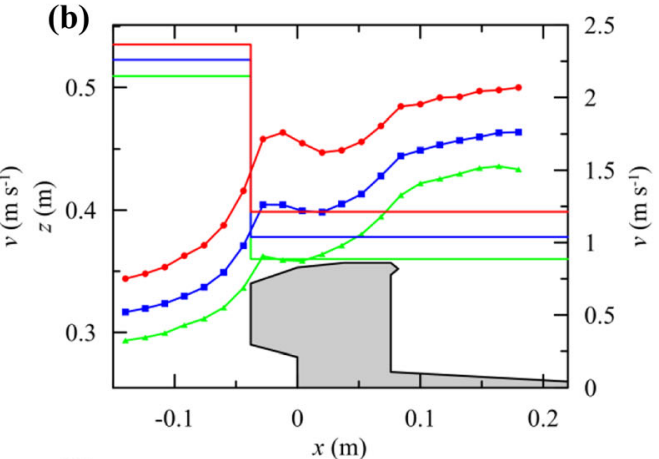

(d)

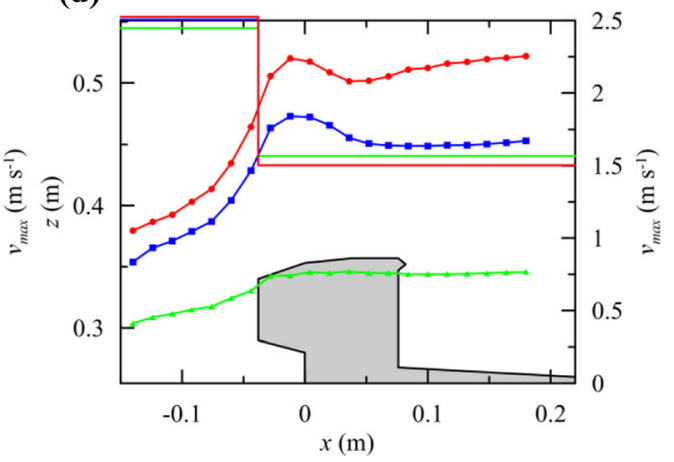

Fig. 9 Average distribution of maximum velocity along the streamwise direction of flow over a weir: a 1:50; b-d 1:25; $h=0.3 \mathrm{~m} ;$ WF01 (a), WF04 (b), WF07 (c), and WF10(d)—green line (triangles); WF02 (a), WF05 (b), WF08 (c), and WF11(d)—blue line (squares); WF03 (a), WF06 (b), WF09 (c), and WF12(d) — red line (circles); respective critical flow velocities are provided for reference (solid lines)

instants. A multi-pass method with a decreasing interrogation window size is used with a $50 \%$ overlap. The size of the starting window is 128 by 128 pixels, and the size of the resulting window is 32 by 32 pixels. Moreover, a geometric mask is applied to a sequence of images to increase the accuracy of calculations in the vicinity of the water surface and the physical model edges. Quiver velocity graphs presenting PIV measurements and complementary line plots are derived using the Golden Software Grapher 11 package.

\subsection{Test Cases}

The measurements are carried out for three initial water depths corresponding to hydrostatic conditions for the model scale of 1:25 and one water depth for the 1:50 model scale. Three net discharges for each case are produced by pump 2. Two series of measurements are carried out for each fixed initial depth and net discharge to provide 1200 instantaneous velocity fields at $10 \mathrm{~Hz}$ and $50 \mathrm{~Hz}$ sampling frequencies. The data collected at the $10 \mathrm{~Hz}$ sampling frequency are used to study the steady state characteristics of flow over the weir, while the $50 \mathrm{~Hz}$ sampling rate is used to analyse the formation and propagation of vortex structures in a region adjacent to the weir crest. PIV measurements are complemented by the monitoring of the net flow discharge and free-surface position at several locations in front of, above, and behind the weir. Basic parameters of weir flow tests are summarised in Table 1.

\section{Results and Discussion}

\subsection{Weir Flow Structure}

To give some insight into the structure of flow over the weir model, a series of time-averaged velocity vector fields is presented in Figs. 5, 6, 7, 8. The mean values of velocity vector components are calculated on the basis of 1200 instantaneous velocity fields recorded at the $10 \mathrm{~Hz}$ sampling frequency, thus covering an averaging interval of two minutes. The results in Figs. 5, 6, 7, 8 are complemented by spatial information on the maximum flow velocity along the streamwise direction $x$ together with reference critical velocity estimates $\left(v_{\mathrm{c}}\right)$. In this case, the critical velocity is determined as a velocity corresponding to the critical flow, where the Froude number is equal to unity $\left(\mathrm{Fr}=v_{\mathrm{c}}\right.$ $g^{-0.5} \mathrm{~h}^{-0.5}=1$ ). In the region upstream of the weir, the critical velocity is calculated on the basis of upstream depth $\left(h_{\mathrm{u}}\right)$. On the other hand, the critical velocities along the weir crest and further downstream are estimated on the basis of the total head of water above the crest $(H)$. It is 


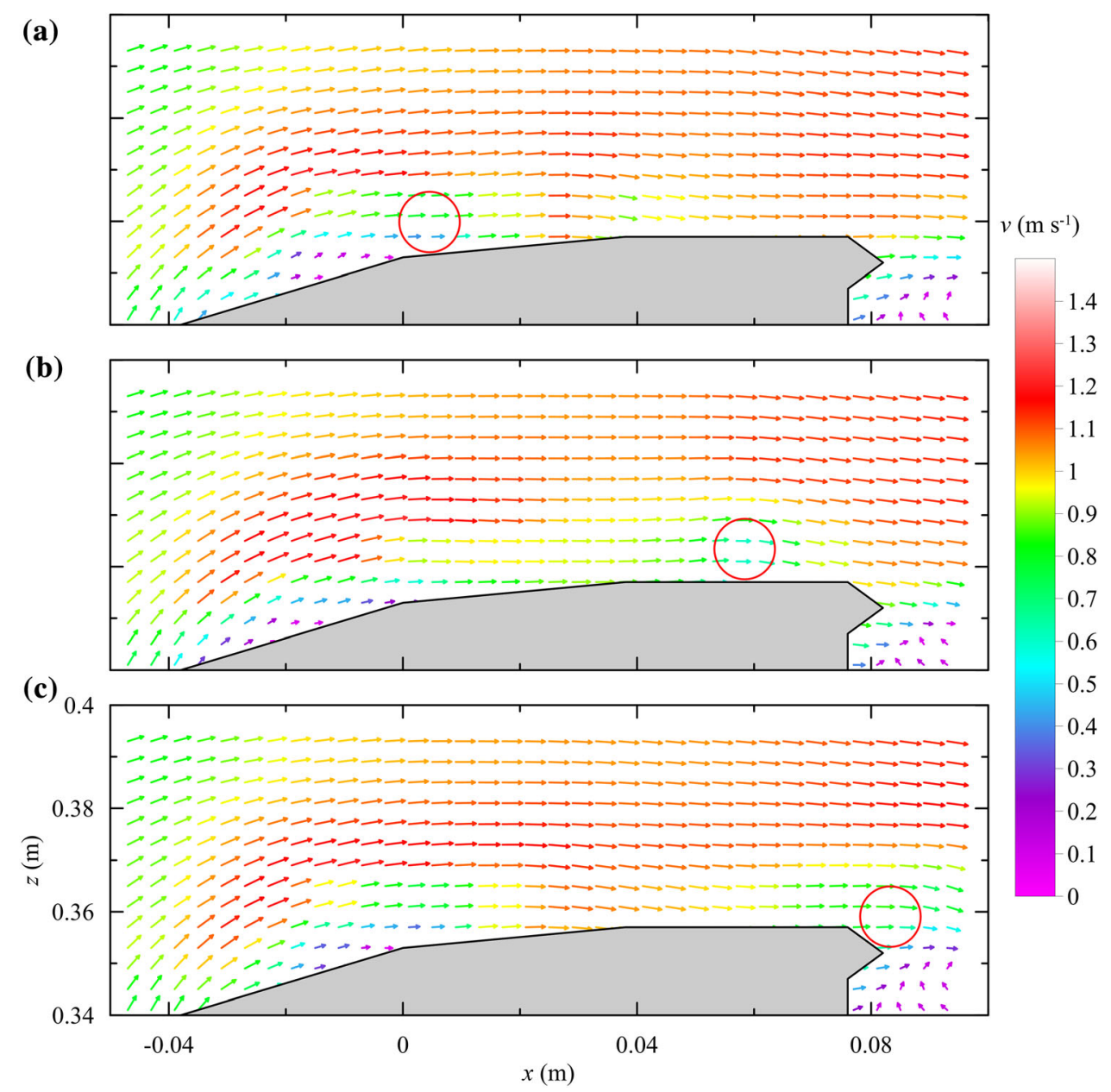

Fig. 10 Evolution of detachment of the stream from the weir crest (WF07); a $t_{0} ; \mathbf{b} t_{0}+0.04 \mathrm{~s} ; \mathbf{c} t_{0}+0.08 \mathrm{~s}$

therefore assumed that the thickness of the main stream tube is approximately constant and equal to $H$ in this region. The streamwise velocity distributions for smaller and larger scale experiments are presented in Fig. 9.

In the case of the smaller model scale (1:50), the flow is characterised by similar spatial patterns as for the larger model scale (Figs. 5a-c, 9a). It may be seen that in the inflow region, the flow regime is subcritical and relatively uniform over depth. When approaching the vertical front of the weir model, water particles accelerate because the vertical upstream weir wall reduces the area perpendicular to the flow. The water flowing over the weir model continues to accelerate. The flow undergoes a transition from the subcritical to the supercritical regime. The maximum velocities grow from 0.5 to $1 \mathrm{~m} \mathrm{~s}^{-1}$ upstream of the weir crest to 1.5 to $2 \mathrm{~m} \mathrm{~s}^{-1}$ at the local maximum above the crest $(x=0 \mathrm{~m})$. Behind the crest, the maximum velocity preserves a slightly lower constant value along the downstream side of the weir model. The stream is first attached to the weir model at the crest and then it overfalls freely above its milder slope downstream of the weir crest. A circulation cell develops under the stream just behind the downstream side of the crest. The water underneath the main stream flows in the reverse direction until reaching the downstream vertical front. In the case of the lowest measured discharge, corresponding to $v_{\mathrm{H}}=0.78 \mathrm{~m} \mathrm{~s}^{-1}$ (WF01), the circulation cell extends to cover the steeper slope of the downstream part of the model as well. For larger discharges, corresponding to $v_{\mathrm{H}}=1$ and $1.8 \mathrm{~m} \mathrm{~s}^{-1}$ (WF02 and WF03), the cell is confined to a triangular region with lower edges formed by the downstream vertical wall and the milder slope of the model.

Generally, the same flow structure applies to physical tests in the larger scale (1:25) with respect to the transition zones from the subcritical flow regime located upstream to the supercritical regime over the weir crest (Fig. 9b-d). It can be seen in Fig. 9b-d that the maximal velocities grow in the streamwise direction, reaching a local maximum at the weir crest. The extreme values may be as high as $2.2-2.3 \mathrm{~m} \mathrm{~s}^{-1}$ for the largest discharges corresponding to 


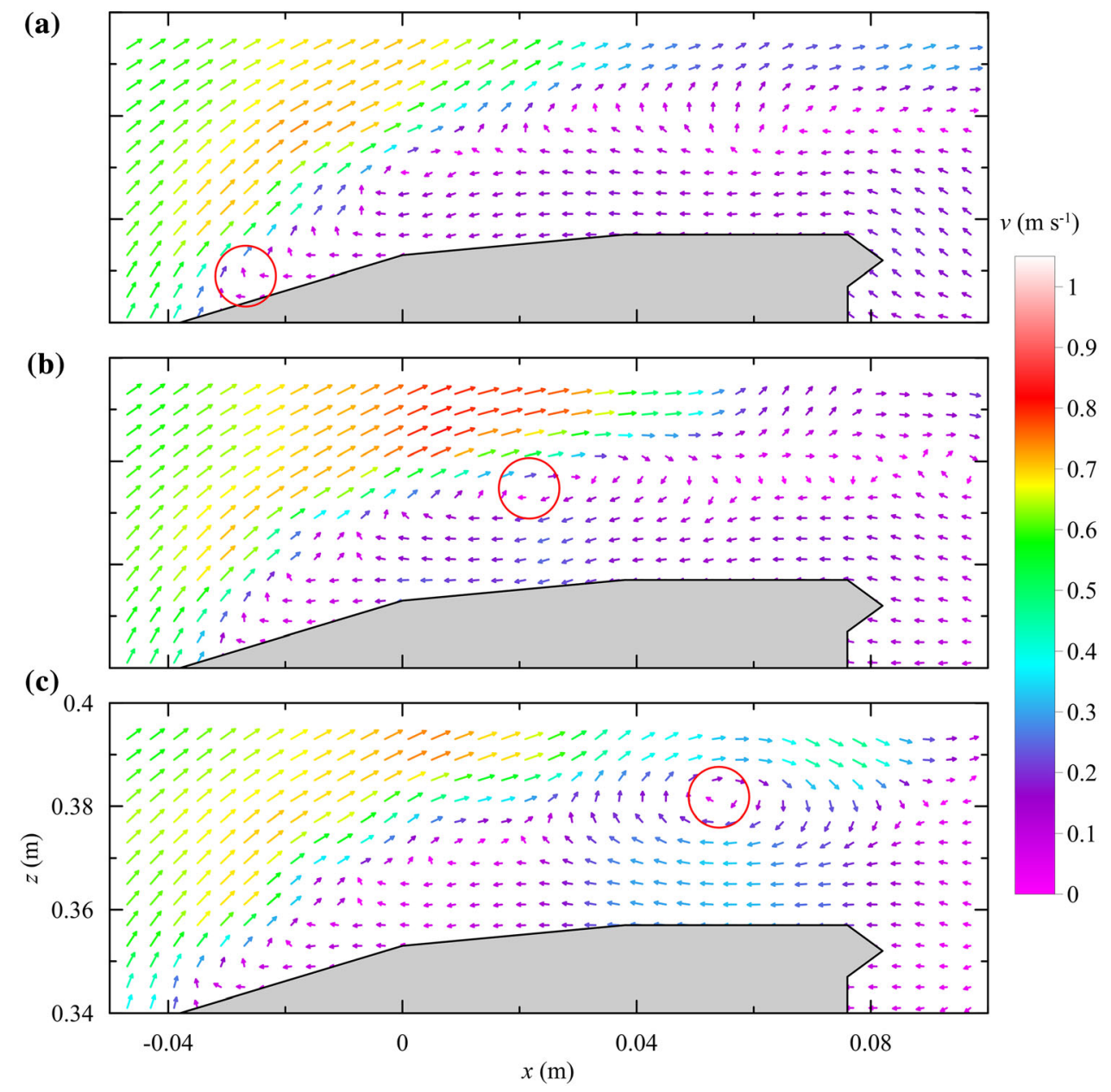

Fig. 11 Formation of a vortex structure above the weir crest (WF10); a $t_{0} ; \mathbf{b} t_{0}+0.14 \mathrm{~s} ; \mathbf{c} t_{0}+0.28 \mathrm{~s}$

$v_{\mathrm{H}}=1.36,1.49$ and $1.56 \mathrm{~m} \mathrm{~s}^{-1}$ and an upstream depth of $0.6 \mathrm{~m}$ (WF06, WF09, WF12). Further downstream, the maximum velocities either remain constant (WF07, WF10) or continue to grow in the remaining cases. It should be noted that the only case in which the flow remains in the subcritical regime upstream and downstream of the weir model is WF10, where the average velocity at the crest is $v_{\mathrm{H}}=0.55 \mathrm{~m} \mathrm{~s}^{-1}$. It is due to the fact that, in this case, the depths of flowing water are relatively large, and the velocity is relatively small, which results in a submerged flow over the weir model. The maximum velocity of flow is always lower than the critical velocity resulting from the thickness of the water layer above the weir crest, as indicated by green lines in Fig. 9d.

\subsection{Vortex Formation}

For lower discharge rates at a larger scale (1:25), the main stream may become detached from the weir crest. The detachment may be partial (Fig. 7a), when the water flow slows down in certain parts of the weir crest, or permanent
(Fig. 8a), when the flow adjacent to the crest is directed opposite to the main stream. The presence and type of detachment implies different flow characteristics with respect to eddy formation downstream of the weir. Figures $10,11,12$ show three typical cases of flow resulting in development of vortex structures starting from a selected time instant $t_{0}$. Figure 10 presents the propagation of stream detachment from the weir crest. It can be seen that the main stream slows down suddenly at the location $x=$ $-0.02 \mathrm{~m}$. The location of the slowdown is identified as the starting point of the detachment of the stream from the weir crest. The detachment propagates further downstream of the weir crest until the lateral boundary of the weir. Behind the weir, the stream freely overfalls above a limited region of relatively calm water and eventually becomes attached to the steeper downstream slope of the weir model. Figure 11 illustrates the formation of vortex structures above the weir crest under hydrodynamic conditions corresponding to a permanently detached flow of water from the weir crest. This kind of detachment is characteristic of flow that remains in the subcritical regime after passing the front 


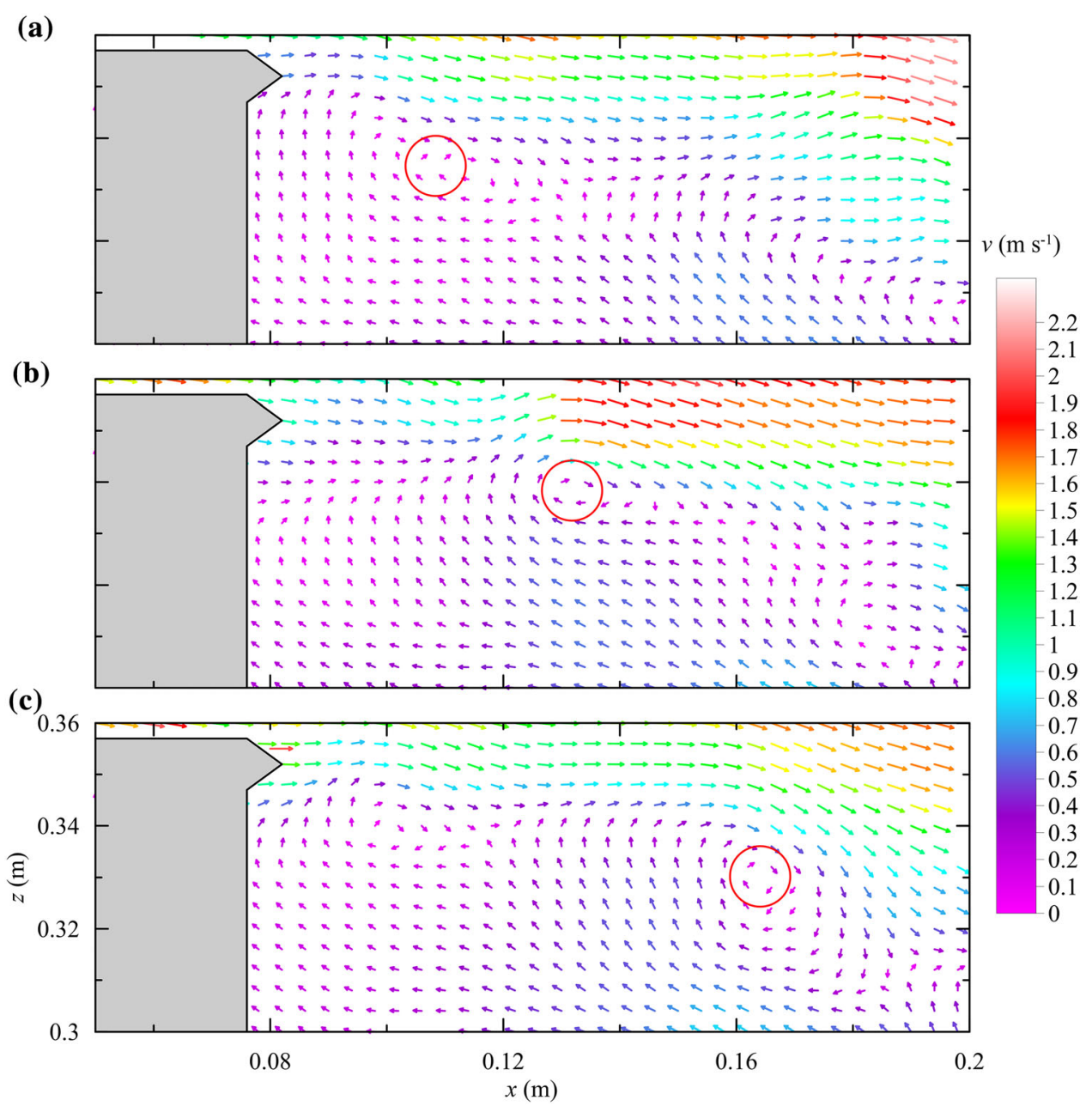

Fig. 12 Formation of a vortex structure behind the weir crest (WF11); $\mathbf{a} t_{0} ; \mathbf{b} t_{0}+0.04 \mathrm{~s} ; \mathbf{c} t_{0}+0.08 \mathrm{~s}$

of the weir crest (Figs. 8a and 9d). In this case, the left end of the weir crest is where vortex structures are first formed $(x=-0.04 \mathrm{~m})$. The vortices are then advected downstream, following a path tangent to the lower boundary of the main stream. Finally, in Fig. 12, the formation of vortex structures at the downstream end of the weir crest is presented. The origin of eddies is located at $x=0.08 \mathrm{~m}$, just behind the weir crest. Again, the vortices propagate downstream in a region adjacent to the lower boundary of the main stream. These hydrodynamic processes are relatively abrupt, since the propagation speed of these evanescent turbulent structures ranges from 0.3 to $1 \mathrm{~m} \mathrm{~s}^{-1}$, and they are formed over a time interval of the order of a hundredth of a second.

\section{Conclusions}

Laboratory experiments are carried out to study the kinematics of flow over a weir. A model of a weir representing a part of the spillway section of the existing Włocławek dam is installed in a wave-current flume. Two model scales 1:25 and 1:50 are investigated for a number of flow discharges corresponding to hydrological events with return periods of 100 and 1000 years. The particle image velocimetry technique is employed to study the evolution of a flow velocity field in a direct vicinity of the modelled damming structure. The system is capable of providing high fidelity velocity fields at sampling rates of $10 \mathrm{~Hz}$ and $50 \mathrm{~Hz}$. The lower acquisition frequency is used for the analysis of flow characteristics corresponding to a stationary flow. The generation and propagation of vortices is analysed on the basis of data acquired at the higher sampling rate.

The flow over the weir model exhibits a common general pattern in nearly all analysed test cases. The flow 
regime is subcritical and relatively uniform over depth in the inflow region. Further downstream, it accelerates due to a decrease in the area perpendicular to the flow, which is limited by the weir crest and free water surface. The maximum velocities grow from $0.5-1 \mathrm{~m} \mathrm{~s}^{-1}$ upstream of the weir crest to $1.5-2 \mathrm{~m} \mathrm{~s}^{-1}$ at the local maximum above the crest. The flow undergoes a transition from the subcritical to the supercritical regime, with the exception of the test case corresponding to the highest upstream depth of over $0.6 \mathrm{~m}$ and the lowest discharge corresponding to an average velocity at the crest of $0.55 \mathrm{~m} \mathrm{~s}^{-1}$, where the flow remains permanently subcritical along the flume. Behind the weir model, a reverse transition from the supercritical to the subcritical regime occurs, resulting in a hydraulic jump.

The geometry of the weir results in the development of a characteristic circulation cell. For lower discharges, the cell is wider, covering the entire weir crest, and is accompanied by the detachment of the main stream from the crest. In the case of the lowest measured discharge, corresponding to an average velocity at the crest of $0.78 \mathrm{~m} \mathrm{~s}^{-1}$, the cell extends to cover the steeper slope of the downstream part of the model as well. For larger discharges, corresponding to average velocities at the crest of 1 and $1.8 \mathrm{~m} \mathrm{~s}^{-1}$, the cell is confined to a triangular region behind the weir crest.

The presence of the weir model and sudden changes in the flow regime result in the formation of vortex structures, which propagate along the lower edge of the main stream tube. In a fully subcritical regime, when the average velocity at the crest reaches approx. $0.6 \mathrm{~m} \mathrm{~s}^{-1}$, origin of eddies is located at the upstream end of the weir crest, as the main stream remains detached from the crest. On the other hand, for a higher average flow velocity at the crest of approx. $1.2 \mathrm{~m} \mathrm{~s}^{-1}$, vortexes are formed at the downstream end of the crest. These turbulent structures propagate at speeds ranging from 0.3 to $1 \mathrm{~m} \mathrm{~s}^{-1}$ and are formed in hundredths of a second.

Open Access This article is licensed under a Creative Commons Attribution 4.0 International License, which permits use, sharing, adaptation, distribution and reproduction in any medium or format, as long as you give appropriate credit to the original author(s) and the source, provide a link to the Creative Commons licence, and indicate if changes were made. The images or other third party material in this article are included in the article's Creative Commons licence, unless indicated otherwise in a credit line to the material. If material is not included in the article's Creative Commons licence and your intended use is not permitted by statutory regulation or exceeds the permitted use, you will need to obtain permission directly from the copyright holder. To view a copy of this licence, visit http://creativecommons. org/licenses/by/4.0/.

\section{References}

1. Novak P, Moffat AIB, Nalluri C, Narayanan R (2007) Hydraulic structures, 4th edn. CRC Press, London. https://doi.org/10.1201/ 9781315274898

2. Ankiersztejn I (2013) The lower vistula cascade. Acta Energetica 16:70-74. https://doi.org/10.12736/issn.2300-3022.2013305

3. Szydłowski M, Gąsiorowski D, Szymkiewicz R, Zima P, Hakiel J (2015) Hydropower potential of the lower Vistula. Acta Energetica 22:18-25. https://doi.org/10.12736/issn.2300-3022. 2015102

4. Tersa A (2013) Barrage in Włocławek. Acta Energetica 16:79-90. https://doi.org/10.12736/issn.2300-3022.2013306

5. Adrian RJ (2005) Twenty years of particle image velocimetry. Exp Fluids 39:159-169. https://doi.org/10.1007/s00348-0050991-7

6. Jodeau M, Hauet A, Paquier A, Le Coz J, Dramais G (2008) Application and evaluation of LS-PIV technique for the monitoring of river surface velocities in high flow conditions. Flow Meas Instrum 19:117-127. https://doi.org/10.1016/j.flowmea sinst.2007.11.004

7. Muste M, Fujita I, Hauet A (2008) Large-scale particle image velocimetry for measurements in riverine environments. Water Resour Res 44:1-14. https://doi.org/10.1029/2008WR006950

8. Le Coz J, Hauet A, Pierrefeu G, Dramais G, Camenen B (2010) Performance of image-based velocimetry (LSPIV) applied to flash-flood discharge measurements in Mediterranean rivers. J Hydrol 394:42-52. https://doi.org/10.1016/j.jhydrol.2010.05. 049

9. Gunawan B, Sun X, Sterling M, Shiono K, Tsubaki R, Rameshwaran P, Knight DW, Chandler JH, Tang X, Fujita I (2012) The application of LS-PIV to a small irregular river for inbank and overbank flows. Flow Meas Instrum 24:1-12. https:// doi.org/10.1016/j.flowmeasinst.2012.02.001

10. Patalano A, García CM, Rodríguez A (2017) Rectification of image velocity results (RIVeR): a simple and user-friendly toolbox for large scale water surface particle image velocimetry (PIV) and particle tracking velocimetry (PTV). Comput Geotech 109:323-330. https://doi.org/10.1016/j.cageo.2017.07.009

11. Bagheri S, Kabiri-Samani A (2020) Simulation of free surface flow over the streamlined weirs. Flow Meas Instrum 71:101680. https://doi.org/10.1016/j.flowmeasinst.2019.101680

12. Dizabadi S, Hakim SS, Azimi AH (2020) Discharge characteristics and structure of flow in labyrinth weirs with a downstream pool. Flow Meas Instrum 71:101683. https://doi.org/10.1016/j. flowmeasinst.2019.101683

13. Wang Y, Wang W, Hu X, Liu F (2018) Experimental and numerical research on trapezoidal sharp-crested side weirs. Flow Meas Instrum 64:83-89. https://doi.org/10.1016/j.flowmeasinst. 2018.10.005

14. Vaghefi M, Radan P, Akbari M (2019) Flow pattern around attractive, vertical, and repelling T-shaped spur dikes in a mild bend using CFD modeling. Int J Civ Eng 17:607-617. https://doi. org/10.1007/s40999-018-0340-x

15. Carvalho RF, Amador AT (2009) Physical and numerical investigation of the skimming flow over a stepped spillway. Advances in Water Resources and Hydraulic Engineering. In: Proceedings of 16th IAHR-APD Congress and 3rd Symposium of IAHR-ISHS, Springer, pp. 1767-1772

16. Medhi BJ, Singh A, Thokchom AK, Mahapatra S (2019) Experimental and computational study on flow over stepped spillway. J Mech Sci Technol 33:2101-2112. https://doi.org/10. 1007/s12206-019-0116-5 
17. Khodier MA, Tullis BP (2018) PIV measurements for oscillating liquid nappe. J Hydro-environ Res 19:237-242. https://doi.org/ 10.1016/j.jher.2017.11.002

18. Peltier Y, Dewals B, Archambeau P, Pirotton M, Erpicum S (2018) Pressure and velocity on an ogee spillway crest operating at high head ratio: experimental measurements and validation. J Hydro-environ Res 19:128-136. https://doi.org/10.1016/j.jher. 2017.03.002

19. Heidari T, Shahni Karamzadeh N, Ahadiyan J (2019) An experimental investigation of convergent rectangular surface jets: spreading characteristics of horizontal flow over the bed of deep and stagnant ambient water. Int J Civ Eng 17:443-456. https:// doi.org/10.1007/s40999-018-0350-8
20. Paprota M, Sulisz W, Reda A (2016) Experimental study of wave-induced mass transport. J Hydraul Res 54:423-434. https:// doi.org/10.1080/00221686.2016.1168490

21. Paprota M (2017) Experimental study on wave-current structure around a pneumatic breakwater. J Hydro Environ Res 17:8-17. https://doi.org/10.1016/j.jher.2017.09.002

22. Paprota M (2019) Particle image velocimetry measurements of standing wave kinematics in vicinity of a rigid vertical wall. Instrum Exp Tech 62:277-282. https://doi.org/10.1134/ S0020441219020234

23. Adrian RJ (1991) Particle imaging techniques for experimental fluid mechanics. Annu Rev Fluid Mech 23:261-304. https://doi. org/10.1146/annurev.fl.23.010191.001401 